\title{
Public and community conservation of biodiversity-rivalry or cooperation?
}

\author{
Lenka Slavíková ${ }^{\circledR}-$ Zdenka Smutná $^{1}-$ Marta Žambochová $^{1}-$ Vladislav \\ Valentinov $^{2}$ \\ ${ }^{1}$ Faculty of Social and Economic Studies, J. E. Purkyně University, Ústí nad Labem, Czechia \\ ${ }^{2}$ Leibniz Institute of Agricultural Development in Transition Economies (IAMO), Halle (Saale), Germany \\ ${ }^{\otimes}$ lenka.slavikova@ujep.cz
}

\begin{abstract}
Although private or community initiatives for biodiversity conservation (such as land trusts) have a strong tradition in many countries, rigorous evidence of recently evolved movements in post-socialist countries is missing. This study describes the evolution of Czech land trust movement and analyses their representatives' motivation for engagement in biodiversity conservation. It also investigates the intensity of interaction among public and land trust conservation efforts. For this purpose, we identified localities in which the territory managed by Czech land trusts overlaps with small-scale public nature reserves managed by regional governments. We conducted semi-structured face-to-face interviews with representatives of all NGOs and regional officials in-charge. Our qualitative analysis revealed that some regional biodiversity conservation officials see land trusts as partners, but others are rather indifferent to, or uninformed about, their activities. Additionally, land trust representatives see themselves as complementing the public effort: their main motivation for engagement is to facilitate biodiversity conservation in addition to the public provision.
\end{abstract}

\section{Highlights for public administration, management and planning:}

- Biodiversity conservation organised on a voluntary basis by communities and NGOs represented by land trust movement is a worldwide phenomenon breaking into the post-socialist reality.

- There are different types of legal and financial instruments that enhance the capacity for NGO conservation-in Czechia these are not systematically applied.

- In Czechia, cooperation between regional and land trust conservation actors at overlapping territories varies significantly and is driven mainly by personal relationships rather than institutional arrangements.

- More systematic engagement and support of different types community conservation actors shall be promoted politically - it would bring more capacities for biodiversity conservation.

\section{Keywords}

Biodiversity conservation, Cooperation, Community, NGOs, Land trust, Czechia

\section{Received:}

10 April 2019

Received in revised form: 1 June 2020

Accepted:

4 June 2020

\section{Introduction}

Biodiversity conservation is considered as a top priority of many international policies (e.g., UN Sustainable Development Goals; European Natura 2000). Within the European Union, the governance of biodiversity conservation is multi-level, with jurisdictions shared between European, national, regional and local levels (Kluvánková-Oravská et al. 2009). Non-governmental initiatives pursued by in- dividual landowners and non-governmental organizations (NGOs) also affect practical biodiversity conservation and amend governmental efforts. The history of co-development of public and private (or community) conservation, and their mutual linkages, differ significantly across countries and continents. Although it may be assumed that both systems interact closely, aiming at same ultimate goal, there has not been much empirical evidence to support this assumption, especially when considering post-socialist Europe (Slavíková et al. 2017). 
In Czechia, after the fall of communism in 1989, a robust multi-level system of territorial biodiversity conservation developed building on the previous state driven conservation starting at 1956. Currently, about $15 \%$ of the Czech territory is under some type of large-scale state biodiversity protection (national parks, protected landscape areas). In addition, hundreds of so-called "small-scale nature reserves" have been established at the regional level, many of them being managed by 13 Czech regional governments. Upon entering the EU in 2004, the Czech government established another 'layer' of Natura 2000 sites to protect selected species and habitats of European importance (Pražan et al. 2005). Different types of publicly-protected territories, as well as the jurisdictions of numerous public administration bodies over them (Czech Nature Protection Law 1992), overlap (Machar 2012). The evaluation of the efficiency of the comprehensive public system is difficult (as is the case with most conservation policies: see Wätzold \& Schwerdtner 2005). Moreover, there is no generallyaccepted approach on how to evaluate the effectiveness of management practices in protected areas (Pechanec et al. 2018).

Additionally, alongside but independent from this development, the grassroots, non-profit biodiversity conservation movement has been growing in Czechia from late 1990s' onwards. This movement was inspired by land trusts in Great Britain and the United States (Selinske et al. 2019). In long-lasting democracies worldwide, such private or community initiatives have a long tradition and have been sufficiently mapped (Campopiano 2006; Bennett et al. 2018; Graves et al. 2019); in post-socialist European countries; however, newborn grassroots conservation movements have received little attention in academic literature (Librová \& Pelikán 2016; Balázsi 2018; Ratinger et al. 2020).

The goal of this study is threefold. First, we outline the evolution and function of Czech biodiversity conservation land trusts as organized under the Czech Union for Nature Conservation (the largest grassroots organization). Second, we discuss their members' motivations for engagement, based on interviews with selected land trust representatives. Third, we aim to answer the following questions: how, and to what extent, do parallel systems of land trusts and public biodiversity conservation represented by regional officers interact? Do they see each other as complementary or conflicting? Motivations of land trust representatives were explained through the lens of different economic theories explaining the NGO existence (see
Table 1 for the overview). For capturing mutual interactions, we identified cases in which the territory managed by Czech conservation land trusts overlaps with public small-scale nature reserves managed by regional governments. We undertook semistructured face-to-face interviews with all representatives of NGOs and regional officers in-charge. The recorded interviews were transcribed and interpreted mainly with the use of thematic content analysis (Schreier 2014).

The paper consists of three sections. First, we review the literature on land trusts worldwide and compare it with the Czech situation. Then, we describe our research design, including economic theories for the NGO existence, data collection and evaluation. Finally, we address the research questions and discuss their broader context and implications.

\section{Purpose and function of biodiver- sity conservation NGOs}

In this paper, the term 'community conservation' is used to describe work of 'land trusts' - as such they into some extent serve as synonyms, although community conservation of biodiversity embodies different types of initiatives and actors than just land trusts. It needs to be stressed, also, that in the literature, different types of NGOs coowning the land are labelled as 'land trusts' too, even if biodiversity conservation is not their primary goal (e.g., see evidence on community land trusts in Moore \& McKee 2012).

\subsection{Land trusts worldwide}

In the U. S. and Australian contexts, land trusts are typically NGOs operating at national, regional and local scales, with the purpose of providing stewardship of privately-owned protected areas. They may work on their own, or in cooperation with government agencies (Selinske et al. 2019). Their function varies across the world. The only universal definition was proposed by The Land Trust Alliance (LTA), which describes a land trust as any organization that acts directly to conserve land (LTA 2020). The history of land trusts dates back to the $19^{\text {th }}$ century, when the first such organization, Trustees of Reservation, was established in the United States, in 1891 (Campopiano 2006). Nowadays, thousands of land trusts operate all around the world, some of them across national borders. The most famous is The Nature Conservancy, which 
protects more than 125 million acres of the land in 79 countries (TNC 2020).

The main difference between land trusts lies in their approach to land acquisition. While in most European countries land trusts prefer to buy the land, in the United States and Australia their stewardship mainly takes the form of conservation easements (Merenlender et al. 2004; Müllerová 2013). Conservation easements (CEs) are voluntary legal agreements restricting some property rights with the aim to protect biodiversity. Demanders - typically land trusts or government agencies - buy, or are granted certain property rights on land, and become responsible for the monitoring and protection of this land under specific conservation values (Horton et al. 2017; Graves et al. 2019). Landowners giving up part of their rights may receive some financial benefits, including income, tax credits, or tax relief on their depreciated property value. Landowners are significantly motivated by these financial incentives to place a $\mathrm{CE}$, for instance on their inferior land (Bastian 2017). This arrangement is beneficial for both parties: the land owner does not lose the land entirely, and the land trust does not need significant resources for land buying-out (Horton et al. 2017; Graves et al. 2019). Direct payment programs, conservation developments, habitat exchanges (species banking), forest or rangeland carbon offsets, grassbanking, pop-up habitats are common tools through which land trusts may ensure the biodiversity conservation of privatelyowned land (Bennett et al. 2018).

A major part of land trust resources comes from private donations. According to Merenlender et al. (2004), however, in most countries, land trusts also count on government funding and public subsidies to cover their land acquisition and operational costs. The evaluation of land trust conservation achievements is, therefore, a legitimate requirement. Self-evaluation systems are put in place by large and powerful organizations, such as The Nature Conservancy, but are rather lacking for the majority of small NGOs (Alexander \& Hess 2011). The multifunctionality of land trusts (environmental education, awareness raising, policy co-development, etc.) also makes their evaluation challenging. (Larson et al. 2014; Selinske et al. 2019).

Despite the positives of land trusts overall, some studies indicate their weaker points. For instance, landowners can be suspicious towards land trust activities (Bastian 2017), and misuse of resources has been reported in the past (Campopiano 2006). In the United States, these issues resulted in the development of the land trust certification scheme, provided by the Land Trust Alliance (Campopiano
2006). It can be concluded, however, that land trusts, supported by CEs, other institutionalised tools and public funding, are considered as integral to biodiversity conservation, and that land trusts significantly complement the public protected areas worldwide (Graves et al. 2019).

\subsection{The land trust movement in Czechia}

In 1997, the first land trusts were established in Czechia under the umbrella of the Czech Union for Nature Conservation (ČSOP). They explicitly modelled on land trust organisations abroad. Their purpose and activities aimed directly at land conservation to protect biodiversity.

The ČSOP was founded in 1979 (under the communist regime) as one of the first grassroots organisations for biodiversity protection. It consisted of volunteers organized in dozens of local chapters that cooperated with state nature reserve management agencies at the local scale, in grass moving, succession prevention, etc. After 1989, the ČSOP went through a phase of dynamic institutional evolution (in the early 1990s, it had a membership of about 10000 people all around Czechia: ČSOP 2020b), but its mission to conserve biodiversity through the voluntary contribution of its members remained the same. The main institutional change was decentralization of decisionmaking: local chapters transformed into independent NGOs, i.e. individual legal entities. Some of these local chapters decided to buy or rent the land they worked to conserve, thus becoming land trusts. In essence, their field work remained the same as before 1989, but now they worked on "their land". Private ownership on longterm leases of the conserved territory is emphasized as an effective arrangement for avoiding conflicts. This strategy, however, faces financial constraints. In case of sufficient capacities land trusts also help with management practices at other territories.

Nowadays, there are 62 Czech land trusts recorded in ČSOP statistics (of which 30 are ČSOP local chapters out of 300 existing ones), undertaking biodiversity conservation at more than 3500 ha of land. Both numbers have grown steadily over the past 20 years. From the total acreage of land conserved by land trusts, about $9 \%$ is owned by land trusts, $30 \%$ is rented from owners under longterm contracts, and almost $40 \%$ is managed by land trusts with the permission of the owners (ČSOP 2020a). The ČSOP headquarters, in Prague, receive regular financial contribution from the Czech Ministry of the Environment and provides coordination and methodological guidance to local land 
trusts. The headquarters have also developed a land trust certification scheme, to bolster the credibility of decentralized conservation (ČSOP 2020c). Next to ČSOP oldest and largest land trust movement in Czechia, there are also many other independent private of community initiatives that due to their fragmentation stayed outside of the research focus of this paper.

The main financial resource for land acquisition is private donations. Since 2003, the ČSOP headquarters have run the national campaign called 'Room for Nature', with the aim to collect money for more land buy-outs. There are also donation initiatives organised at the local level. In Czechia, there is no systematic governmental support for individual land trusts, although particular organisations can apply for the grants for biodiversity conservation enhancement, environmental education programs, etc. If an individual or a firm donates money to an NGO, their income tax is reduced. However, there are no other legal tools, such as CEs, that provide financial incentives for landowners to cooperate with land trusts. As a result, the extent of the conserved land is limited. The ability of land trusts to cover annual administration and management costs and their strategies for doing so vary significantly (Růžička \& Moravec 2008, see also Section 3). Incentives other than financial are necessary, e.g. farmers taking biodiversity enhancement into consideration (the philanthropic farmer, as described by Slavíková \& Raška 2019, for instance). Moreover, from the institutional point of view, there is no specific instrument linking public conservation priorities with the endeavour of Czech land trusts.

\section{Methodology: data collection and processing}

To document land trust representatives' motivations for engagement in biodiversity conservation and their relationship with public biodiversity conservation officials, we conducted qualitative interviews with open-ended questions (Supplement 1). Interviews included questions on the respondent's background, their organisation's biodiversity protection and management practices, and their cooperation with public biodiversity protection agencies. At the end of the interview, respondents expressed their agreement or disagreement with five statements describing reasons for their decision to establish a land trust. These statements were derived from different economic theories explaining the existence and function of NGOs (Will et al. 2018; Valentinov et al. 2015; Wandel \& Valentinov 2014). Based on an overview of these theories (Murray Svidroňová et al. 2016), we modified rele-

Table 1 Selected economic theories explaining the existence of NGOs, and derived statements

\begin{tabular}{|c|c|c|}
\hline Theory & Theory Characteristics & Derived Statement \\
\hline $\begin{array}{l}\text { Supply Side Theory } \\
\text { (or Entrepreneurship } \\
\text { Theory) }\end{array}$ & $\begin{array}{l}\text { NGOs are a reflection of demand heterogeneity, } \\
\text { served and created by entrepreneurs seeking } \\
\text { to maximize nonmonetary returns }\end{array}$ & $\begin{array}{l}\text { S1: The land trust was established } \\
\text { because of our own interests, } \\
\text { to satisfy our members' need to help } \\
\text { in biodiversity protection. }\end{array}$ \\
\hline $\begin{array}{l}\text { Heterogeneity Theory } \\
\text { (or Public Goods Theory, } \\
\text { or Governmental } \\
\text { Failure Theory) }\end{array}$ & $\begin{array}{l}\text { Unsatisfied demand for public and quasi-public } \\
\text { goods in situations of demand heterogeneity leads } \\
\text { to emergence of non-profit providers }\end{array}$ & $\begin{array}{l}\text { S2: The public administration lacks } \\
\text { the capacity and interest to provide } \\
\text { sufficient biodiversity conservation; } \\
\text { this is why we established the land trust. }\end{array}$ \\
\hline Rurality Theory & $\begin{array}{l}\text { Discrepancy between the standard of living between } \\
\text { urban and rural areas (in connection to lower rate } \\
\text { of return for for-profit activities) creates a niche } \\
\text { for rural NGOs (Valentinov 2009) }\end{array}$ & $\begin{array}{l}\text { S3: Land trust was founded } \\
\text { to incentivise local people to engage } \\
\text { in local biodiversity conservation. }\end{array}$ \\
\hline $\begin{array}{l}\text { Interdependence Theory } \\
\text { (or Voluntary Failure } \\
\text { Theory, or Third-Party } \\
\text { Government Theory) }\end{array}$ & $\begin{array}{l}\text { Because of (initially) lower transaction costs, NGOs } \\
\text { precede government in providing public-benefit } \\
\text { goods, but due to "voluntary failures" they develop } \\
\text { synergistic relations with the public sector over time }\end{array}$ & $\begin{array}{l}\text { S4: We saw the option to provide } \\
\text { additional biodiversity conservation } \\
\text { next to the extant public administration } \\
\text { activities, so we established the land trust. }\end{array}$ \\
\hline $\begin{array}{l}\text { Trust Theory } \\
\text { (Contract Theory, } \\
\text { or Market Failure Theory) }\end{array}$ & $\begin{array}{l}\text { Non-distribution constraint renders NGOs more } \\
\text { trustworthy under conditions of information } \\
\text { asymmetry which makes monitoring expensive } \\
\text { and profiteering likely }\end{array}$ & $\begin{array}{l}\text { S5: For people, the land trust represents } \\
\text { a more credible/transparent way } \\
\text { to contribute to biodiversity conservation, } \\
\text { so we established it. }\end{array}$ \\
\hline
\end{tabular}

Source: Anheier 2013, in Murray Svidroňová et al. 2016 (p. 403), modified. 


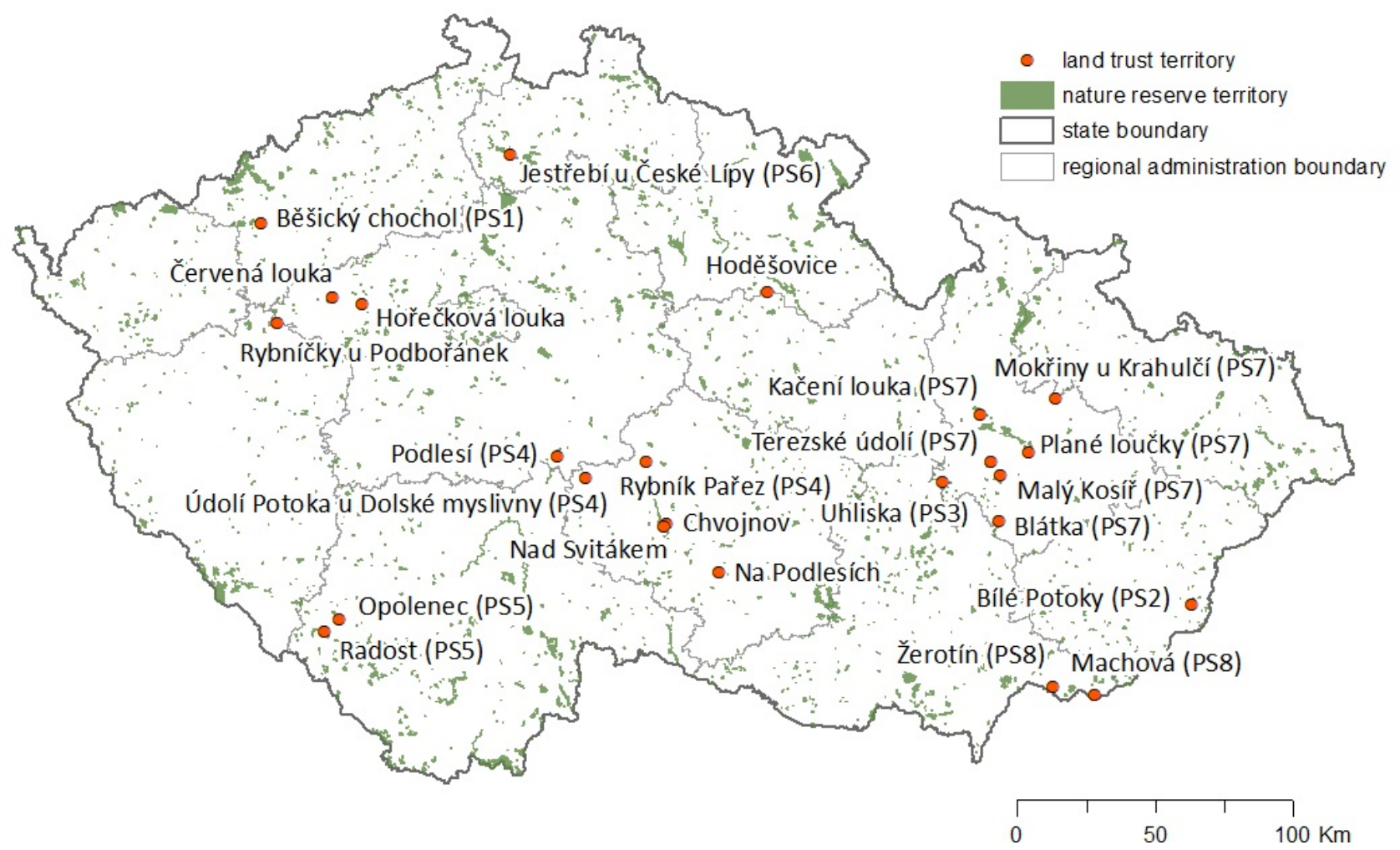

Fig. 1 Overlaps of nature reserves and land trust territories in Czechia. Source: authors based on AOPK (2020)

vant interpretations of NGO emergence taking biodiversity conservation into consideration (Table 1). The respondents' agreement or disagreement with the five statements was expressed on the 5-point scale: -2: 'strongly disagree'; -1: 'rather disagree'; 0: 'neutral', 1: 'rather agree'; 2: 'strongly agree'. To define the respondent pool, we used ČSOP's database to identify all overlap between territories conserved simultaneously by land trusts and regional government agencies (ČSOP 2020d). This enabled us to test both the motivation for engagement of land trust representatives, and their attitudes towards the public conservation system and its performance. Together, there were 12 different land trusts whose territories overlap with public nature reserves managed by nine different regional administrations (Fig. 1). Our intention was to interview representatives from all 12 land trusts and the nine regional offices in charge of nature reserve conservation (see interviews in the Supplement 1). Finally, eight land trust representatives were interviews (their territories are labelled as PS1-PS8 in Fig. 1). Face-to-face semi-structured interviews were undertaken in 2017 and during the first half of 2018. The interviews were recorded and transcribed. Open-ended questions were interpreted qualitatively with the use of thematic content anal- ysis (Schreier 2014). To provide better understanding of the research questions that has not been widely investigated, exploratory approach was applied. Statements ranked on the quantitative scale were analysed with the use of descriptive statistics.

\section{Results}

From the 12 land trusts that met the study's selection criteria, eight representatives agreed to be interviewed (these interviews are coded as PS1-PS8 in the text). The remaining four respondents refused to be interviewed due to personal time constrains, or could not be reached on the contacts available in the ČSOP database (phone, email, address). All nine regional administration officers were available for interview (coded KU1-KU9).

\subsection{Motivations of land trust representatives to conserve the land}

First, land trust representatives were asked the open question about their reasons for the founding and participating in land trusts. One of motivations mentioned was willingness to contribute 
Table 2 Land trust and land trust representatives' characteristics

\begin{tabular}{|c|c|c|c|c|c|c|c|}
\hline \multirow{2}{*}{$\begin{array}{c}\text { Interview No. } \\
\text { (MM/YYYY) }\end{array}$} & \multicolumn{4}{|c|}{ Land trust representative } & \multicolumn{3}{|c|}{ Land trust } \\
\hline & Age & Gender & Employment & $\begin{array}{l}\text { Years in the } \\
\text { land trust }\end{array}$ & $\begin{array}{c}\text { Year } \\
\text { of } \\
\text { foundation }\end{array}$ & $\begin{array}{c}\text { No. of } \\
\text { stable } \\
\text { employees }\end{array}$ & $\begin{array}{c}\text { No. of } \\
\text { volunteers }\end{array}$ \\
\hline $\begin{array}{l}\text { PS1 } \\
(05 / 2017)\end{array}$ & $31-40$ & M & - & 8 (one of the co-founders) & 2010 & 0 & 3 \\
\hline $\begin{array}{l}\text { PS2 } \\
(10 / 2017)\end{array}$ & $71-80$ & M & Retired & 19 (one of the co-founders) & 1999 & 0 & $150-180$ \\
\hline $\begin{array}{l}\text { PS3 } \\
(10 / 2017)\end{array}$ & $41-50$ & $\mathrm{~F}$ & $\begin{array}{l}0,5 \text { teacher } \\
0,5 \text { land trust }\end{array}$ & 16 (one of the co-founders) & 2002 & 3 & 20 \\
\hline $\begin{array}{l}\text { PS4 } \\
(06 / 2017)\end{array}$ & $51-60$ & M & 0,2 land trust & 16 & 1999 & 15 & - \\
\hline $\begin{array}{l}\text { PS5 } \\
(07 / 2017)\end{array}$ & $21-30$ & M & land trust & 10 (one of the co-founders) & 2008 & 2 & 10 \\
\hline $\begin{array}{l}\text { PS6 } \\
(10 / 2017)\end{array}$ & $41-50$ & $\mathrm{~F}$ & land trust & 8 (one of the co-founders) & 2010 & 2 & 30 \\
\hline $\begin{array}{l}\text { PS7 } \\
(02 / 2018)\end{array}$ & $41-50$ & M & land trust & 18 & 2000 & 7 & 0 \\
\hline $\begin{array}{l}\text { PS8 } \\
(02 / 2018)\end{array}$ & $41-50$ & $\mathrm{~F}$ & land trust & 19 (one of the co-founders) & 1999 & 4 & \\
\hline
\end{tabular}

to the conservation of cultural and natural heritage (with both kinds of heritage considered to be linked closely). There was also the need to support the engagement of local people and to help with the organisation of children's and youth's leisure time. At places where the engagement is long-term and successful, land trusts can rely on a stable base of volunteers. As summarized by PS2: "For co-operative biodiversity conservation, a strong and functioning community is crucial". PS7 and PS8 emphasised that the foundation of a land trust systematised activities that had been in place already, such as interactions with landowners.

To better capture and compare the motivations of land trust representatives, five statements derived from different economic theories of NGO emergence and function were submitted to them. Fig. 2 summarizes average responses to statements S1-S5 and the variability of these responses. It shows that the intention to provide additional biodiversity conservation next to the one provided by state authorities (S4) is the prevailing reason for founding a land trust. This response was also the least variable, meaning that the level of agreement among land trust representatives was the highest. By contrast, the statement of "governmental criticism" - that land trusts are founded because of perceived insufficiency of, or lack of interests by, the public administration (S2)-elicited the strongest opposition. This conclusion is into some extent contrasting with findings of Ratinger et al. (2020) who - based on four Czech case studies - explained so-called elite-driven NGO occurrence with the lack of interest from public bodies. Some land trust representatives, however, expressed some degree of criticism of the public system (see Section 3.2). The largest diversity of opinion among land trust representatives relates to S3: engagement of local people in local biodiversity protection is a crucial reason for some, but relatively unimportant for others.

The interviews also revealed large differences between land trusts in the way they operate, namely in their degree of professionalisation and in the number of permanent employees vs. volunteers. On the one hand, there are land trusts with heterogeneous activities that are successful in fundraising, including funding from large European projects. Biodiversity conservation is only one of their activities, next to environmental education and contractual work, e.g. greenery maintenance for municipalities and firms. This ensures stability, but may jeopardise the original purpose of the land trust foundation: "We still need to keep in mind 


\section{sciendo}

the original values, and not to became too commercial... We need to consciously refer to our mission and adhere to it" (PS4). A different strategy is pursued by land trusts oriented towards community empowerment. These organisations aim at engaging large numbers of volunteers, and public funding is viewed as a source of instability: "Projects end, and the organization is threatened with the discontinuity of financing. Furthermore, people need to deal with the administration of projects rather than field work. We decided not to pursue this strategy anymore" (PS2). Doubts about the sustainability of land trust activities is raised by representatives of less professionalised land trusts which cannot afford more staff, and do not rely on large numbers of volunteers (PS1 and PS3). They mention their concerns about shrinking financial and personnel capacity: "In the past years I have seen the decreasing willingness - especially among young people-to work physically. I also see that people who have been working in non-state biodiversity conservation for decades are tired" (PS3) (compare this attitude with evidence captured in Librová \& Pelikán 2016).

\subsection{Interactions between community and public biodiversity conservation schemes}

The third question concerned the extent and types of interactions between land trust representatives and the public administration, represented by regional officers managing small-scale nature reserves. Where locations of land trusts and public nature reserves overlap, cooperation in biodiversity conservation is to be expected.

The standard legal procedure $(\S 38$, Nature Protection Law 1992) involves the coordination of land trust and public nature reserve activities through an approved nature reserve management plan valid for 10 years. If a land trust owns land in a nature reserve, it should be invited to comment on the preliminary version of the management plan. In some locations, land trusts actively contributed to plan development. In other places, they did not have the chance to consult it, or their suggestions were not incorporated in the plan. As summarized by PS2, "in plans we clarify our practices: what will happen, and where. We do not always agree with regulators, but we are able to find a common ground". Land trusts can come up with innovative approaches to conservation, and it depends on the regional office how and to what extent these

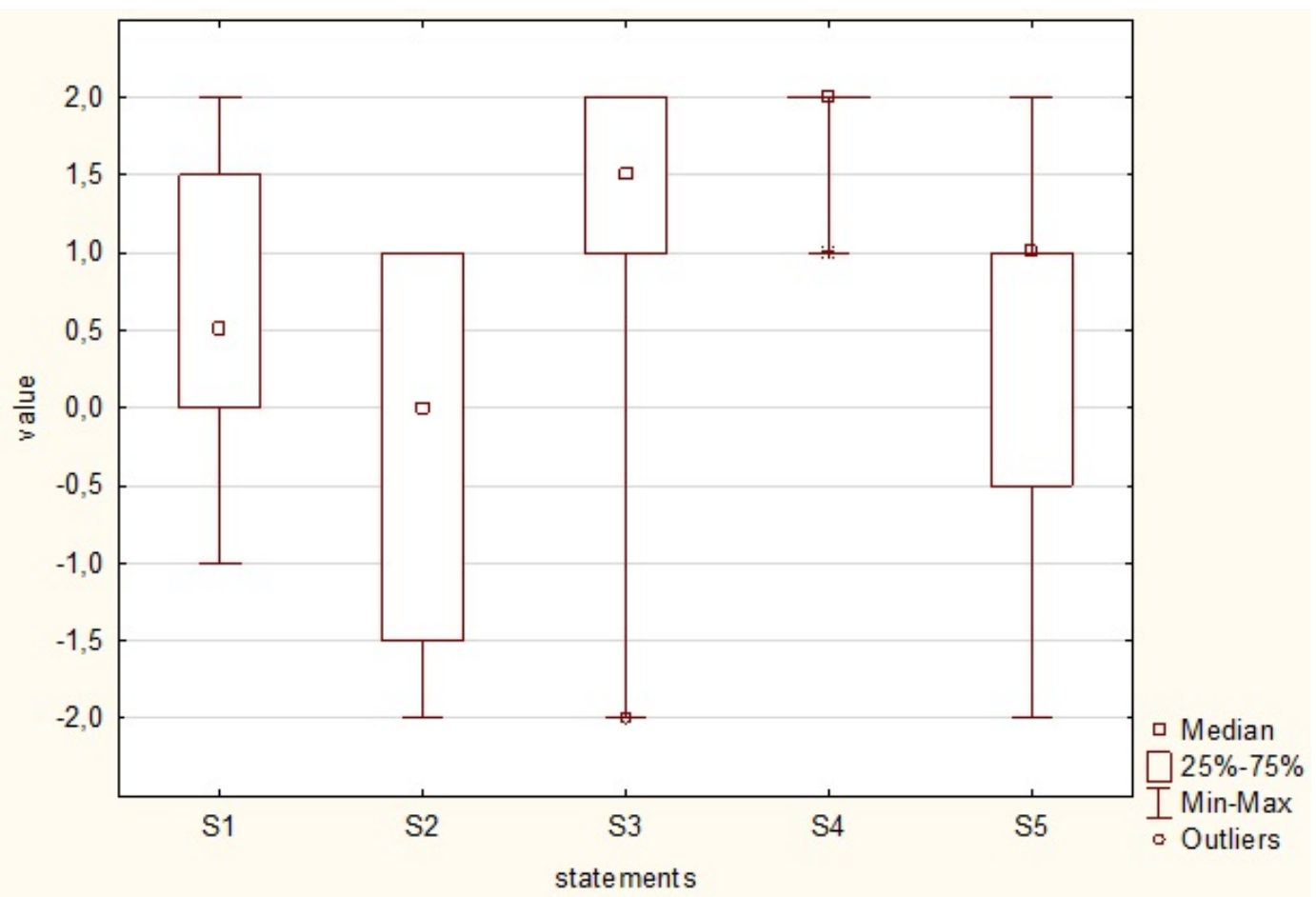

Fig. 2 Responses of land trust representatives to statements S1-S5 (-2: 'strongly disagree'; -1: 'rather disagree'; 0: 'neutral'; 1: 'rather agree'; 2: 'strongly agree'). For statements, see Table 1. Source: authors 
ideas are adopted. "An NGO is not bounded with internal procedures and regulations; it can bring crazy ideas on board" (PS4).

Besides statutory planning procedures, there is space for other types of interaction. Some land trusts wish to maintain closer links with public biodiversity conservation officials: they raise funds for biodiversity inventories, so that more of their territories can become part of public nature reserves (PS7). This helps land trusts to receive regular management subsidies. Other land trusts go to the opposite direction: "We do not want our territories to overlap. It is the opposite: land trust territories are sometimes abstracted from public nature reserve areas because sufficient conservation is already provided by us" (PS2).

Interactions between land trust representatives and regional biodiversity administrators may differ significantly. From the regional office perspective, KU2 describes a very close and successful collaboration and would welcome the increase of land trust activity in the region: "For the land trust, we are the source of management financing. For us, they are ideal partners with low prices, enthusiasm and a real interest in conservation" (KU2). With their ability to organise volunteers (e.g. for grass mowing), land trusts deliver services that, in their absence, would need to be contracted commercially. They deliver the highest standard of the services and complement it with additional activities, such as establishment of springs, pool renovation etc. (PS2). From interviews in was apparent that somewhere land trusts compete in regional selection procedures for management resources and win the contract with the lowest price. At other places they are subject to regular management contributions from the regional office for which they do not compete with commercial firms. Further, some regional officers expressed long-term relationships with land trust representatives, such as being former land trust founders (KU8) or working together in ČSOP previously (KU2).

In other places, awareness of the existence of land trusts and acknowledgement of their potential are lacking. Biodiversity administrator KU7 states that they communicate with land trusts in the same way as with any other landowner whose land is situated in public nature reserves. They are pleased that, contrary to other landowners, land trusts agree with, and support conservation efforts. "Most of the time, we speak to someone, and subsequently we discover that he is active in some kind of an NGO" (KU7). KU3 complements this statement: "I have not heard of land trusts, although I know ČSOP... Is it a problem that their territory overlaps with our nature reserve?". In these regions, land trusts usually do not activate large numbers of volunteers, and their activities are rather small-scale, supported by a narrow group of members and/or paid seasonal workers. Their interactions with regional nature reserve officers are scarce: "We do not directly communicate with land trusts, and we do not meet each other much, either" (KU1). Land trusts and public authorities co-exist rather than cooperate. Regional officers in these regions also express doubts regarding the voluntary engagement of people in biodiversity conservation (KU4). They consider community biodiversity conservation as a commendable but negligible phenomenon that is strongly limited by existing resources (KU1, KU8).

Some land trust representatives criticise the performance of the public biodiversity conservation system. According to PS5, better conservation is provided by a landowner who really cares for the results of conservation, and who aims at long-term landscape stability. In public nature reserves, the necessary management practices are often contracted out to different service providers, following criteria of (lower) price. Contracted firms are difficult to control, and they are not interested in biodiversity enhancement. Furthermore, there are not absolute right or wrong measures in conservation practices; diversity, flexibility and time are required. Land trust representatives have longitudinal experience with the conserved landscape, and this experience accounts for more successful conservation. "If you work as the regional officer, you mainly care for the paperwork, you do not realise measures" (PS1). In addition, other stakeholders in the field are better prepared to reach an agreement when negotiating with the local NGO: "When we talk to land owners, some of them do not like public biodiversity protectors. They do not trust regulators, but they are easy talking to us because there is no coercion and both sides are equal" (PS4). The last statement captures well the main strengths of land trusts: regular contact with people in a certain locality, informal relationships, and strong personal engagement.

\section{Discussion}

Our research shows that Czech land trusts under ČSOP play a active role in biodiversity conservation at the local scale. Even though they are not free of certain problems of their own, their activities are a useful complement to those of the public sector. The intensity of the interaction between land 
trusts and public biodiversity conservation authorities is place-dependent. Social contacts between members of both groups play a key role. Compared with the international scene, there are no specific legal instruments, such as conservation easements, that would formally encourage land trust operations (Horton et al. 2017; Graves et al. 2019). Some public conservation officials see land trusts as partners, while others are rather indifferent, or uninformed about their activities. Additionally, land trust representatives see themselves as complementing (S4), rather than rivalling (S2) public conservation efforts. Evaluation of the performance and outputs of land trust and public biodiversity conservation systems is lacking due to the absence of relevant evidence.

These findings add to recent conceptual contributions to the non-profit literature. Lohmann (2015) saw the non-profit sector as a form of "commons", or collective voluntary action, which cannot be perfectly translated into formal institutions. Will et al. (2018) suggested that NGOs engage in activities that go beyond the range of competence of the function systems of economy and politics; that is, no function system can match the complexity of human undertakings. Lohmann (2015) took these undertakings to be the expression of the inherently active human nature (in contrast, e.g., to the Homo economicus model). In line with Lohmann (2015), our findings show that many people are indeed very active in biodiversity conservation, and that this activity is mainly driven by enthusiasm, intrinsic motivation, creativity, and pro-social behaviour. At the same time, in line with Will et al. (2018), there is room to argue that this willingness pertains to various activities that go beyond the range of competence of the relevant public sector organisations. Land trusts thus have unique functions to fulfil. At the same time, however, as formal institutions, they may be subject to their own shortcomings, such as commercialisation, bureaucratisation, financial shortages, etc. This brings us back to Lohmann (2015), who associated the original nature of nonprofit activities not with non-economic and nonpolitical function systems (as Will et al. 2018, did), but with collective voluntary action, which is informal and rooted in community. Integrating the perspectives of Lohmann (2015) and Will et al. (2018), we note that some elements of collective voluntary action may be subject to ongoing translation into formal institutions.

A broader implication of our suggested interpretation pertains to the sociological debate about the relationship between agency and structure (Dowding 2008, Rafiee et al. 2014). We show that struc- tures, such as public sector and NGOs, are quite important; nevertheless, the complexity of biodiversity conservation opens space for collective voluntary action - a manifestation of agency. Structures are important for standardised and legallyanchored tasks which, however, by virtue of their standardisation, cannot encompass the full complexity of biodiversity conservation. Also, in case of investigated land trusts little ambition has been showed to transform existing public sector structures (Giddens 1984; Sewell 1992). Given the local and independent nature of particular land trusts, large variety of strategies of the NGO structure evolution and transformation have been captured.

\section{Conclusion}

This contribution provides evidence on the ČSOP land trust movement, the largest private/community-based biodiversity conservation endeavour in Czechia. It also investigates to what extent public and community conservation activities are coordinated at localities where they overlap. The underlying assumption is that both, engagement of local people and land trust contribution to predefined biodiversity conservations goals would be actively promoted by the public administration within its sustainable development agenda. We find that land trusts serve as valuable complements of the public biodiversity conservation sector, but the quality of their interaction with public sector officials is place-dependent and reliant on personal contacts. Widespread acknowledgement of, and support for land trust activities are lacking. This situation jeopardises future land trust evolution and prosperity.

Our interviews with land trust representatives revealed different surviving strategies, and related dilemmas, such as professionalization, commercialisation, social capital building etc. In the future, it would be worth investigating which strategies can promote capacity strengthening and the sustainability of community-based biodiversity conservation activities. Such a research could further enrich the current theoretical discussion on NGOs.

\section{Acknowledgement}

The authors acknowledge the funding provided by Czech Science Foundation to the project No. 20-11782S [The nature and dynamics of local land use conflicts in a polyrational arena]. Z.S. thanks 
to the Internal Grant Agency of the Jan Evangelista Purkyně University in Ústí nad Labem, No. UJEP-SGS-45208-15-2002-01 [The concept of regional value added partnership in the agri-food production and rural tourism sectors: proposal for implementation in rural development].

\section{References}

Alexander L, Hess GR (2012) Land trust evaluation of progress toward conservation goals. Conservation Biology 26(1): 7-12.

Anheier HK (2013) Civil society and non-profit organizations: what are the issues? In: 17th International Conference Current Trends in Public Sector Research. Masaryk University, Brno.

AOPK (2020) Maloplošná zvláště chráněná území. Available at: <https://drusop.nature.cz/ost/chrobjekty/zchru/index.php?MZCHU> Retrieved on 3rd January 2020.

Balázsi A (2018) Grassland management in protected areas implementation of the EU biodiversity strategy in certain postcommunist countries. Hacquetia 17(1): 73-84.

Bastian C T, Keske C M, McLeod D M, Hoag D L (2017) Landowner and land trust agent preferences for conservation easements: implications for sustainable land uses and landscapes. Landscape and Urban Planning 157: 1-13.

Bennett D E, Pejchar L, Romero B, Knight R, Berger J (2018) Using practitioner knowledge to expand the toolbox for private lands conservation. Biological Conservation 227: 152-159.

Campopiano M (2006) The Land Trust Alliance's new accreditation program. Ecology LQ 33: 897.

ČSOP (2020a) Pozemkové spolky. Available at: <https://ČSOP.nap.cz/Statistiky-pozemku>

ČSOP (2020b) Historie ČSOP. Available at: <http://www.ČSOP.cz/ index.php?cis_menu $=1 \& \mathrm{~m} 1$ id $=1001 \& \mathrm{~m} 2$ id $=1062 \& \mathrm{~m}_{-}$id old $=1028>$

ČSOP (2020c) Založení pozemkového spolku. Available at: <http://www.ČSOP.cz/index.php?cis menu=1\&m1 id=1003\&m2 id $=1071 \& m 3$ id $=1078 \&$ m_id_old $=1071>$

ČSOP (2020d): Pozemkové spolky. Available at: <https://ČSOP.nap.cz/Prehled.aspx>

Czech Nature Protection Law No. 114/1992 Call. Available at: <https://www.mzp.cz/www/platnalegislativa.nsf/\%24\%240penDominoDocument.xsp?documentId=58170589E7DC0591C125654B004E91C1\&action=openDocument>

Dowding K (2008) Agency and Structure: Interpreting power relationships. Journal of Power 1(1): 21- 36.

Giddens A (1984) The constitution of society: outline of the theory of structuration. University of California Press.

Graves R A, Williamson M A, Belote R T, Brandt J S (2019) Quantifying the contribution of conservation easements to largelandscape conservation. Biological Conservation 232: 83-96.

Horton K, Knight H, Galvin K A, Goldstein J H, Herrington J (2017) An evaluation of landowners' conservation easements on their livelihoods and well-being. Biological Conservation 209: $62-67$.
Kluvánková-Oravská T, Chobotová V, Banaszak I, Slavikova L, Trifunovova S (2009) From government to governance for biodiversity: the perspective of central and Eastern European transition countries. Environmental Policy \& Governance 19(3): 186-196.

Larson E R, Boyer A G, Armsworth P R (2014). A lack of response of the financial behaviors of biodiversity conservation nonprofits to changing economic conditions. Ecology and Evolution 4(23): 4429-4443.

Lohmann Roger A (2015) Voluntary action in new commons. Faculty Scholarship: 760. <https://researchrepository.wvu.edu/faculty_publications/760>

Librová H, Pelikán V (2016) Ethical motivations and the phenomenon of disappointment in two types of environmental movements: Neo-Environmentalism and the Dark Mountain Project. Environmental Values 25(2): 167-193.

LTA (2020) Community conservation. < <ttps://www.landtrustalliance.org/topics/community-conservation>

Machar I (2012) Protection of nature and landscapes in the Czech Republic. Selected current issues and possibilities of their solution. In: Machar I, Drobilova L (Eds) Ochrana Prirody a Krajiny v Ceske Republice I, II. Palacky University, Olomouc.

Merenlender A M, Huntsinger L, Guthey G, Fairfax S K (2004) Land trusts and conservation easements: who is conserving what for whom?. Conservation Biology 18(1): 65-76.

Moore T, McKee K (2012) Empowering local communities? An international review of community land trusts. Housing Studies 27(2): $280-290$

Müllerová H (2013) Pozemkové spolky - alternativní způsob ochrany půdy, flóry a fauny. Institute of state and law of the Czech Academy of Sciences.

Murray Svidroňová M, Vacekova G, Valentinov V (2016) The theories of non-profits: a reality check from Slovakia. Lex Localis Journal of Local Self-Government 14(3): 399-418.

Nature Protection Law (1992) Zákon č. 114/1992 Sb. o ochraně prírody a krajiny.

Pechanec V, Machar I, Pohanka T, Opršal Z, Petrovič F, Švajda J Málková J (2018) Effectiveness of Natura 2000 system for habitat types protection: A case study from the Czech Republic. Nature Conservation 24: 21.

Pražan J, Ratinger T, Krumalová V (2005) The evolution of nature conservation policy in the Czech Republic-challenges of Europeanisation in the White Carpathians Protected Landscape Area. Land Use Policy 22(3): 235-243

Rafiee M, Mirzaee H, Mirzaee A, Hashemzadeh A (2014) The relationship between structure and agency in communicative action theory. Bulletin of Environment, Pharmacology and Life Sciences 3: 141-149.

Ratinger T, Čamská K, Pražan J, Bavorová M, Vančurová I (2020) From elite-driven to community-based governance mechanisms for the delivery of public goods from land management. Land Use Policy (in press). https://doi.org/10.1016/j.landusepol.2020.104560

Růžička T, Moravec J (2008) Věcná břemena a další nástroje pozemkospolkové činnosti v České republice. Ochrana prírody 6 [Czech translation of Bernstein J, Mitchell BA (2005), Parks 15(2), 2005]

Schreier M (2014) Qualitative Content Analysis. In: Flick U (ed) The SAGE handbook of qualitative data analysis. SAGE Publishing, London, pp. 170-183.

Selinske M J, Howard N, Fitzsimons J A, Hardy M J, Smillie K, Forbes J, Knight A T (2019) Monitoring and evaluating the social 


\section{S sciendo}

and psychological dimensions that contribute to privately protected area program effectiveness. Biological conservation 229: 170-178.

Sewell W H (1992) A theory of structure: duality, agency, and transformation. American Journal of Sociology 98(1): 1-29.

Slavíková, L, Syrbe R, Slavík J, Berens A (2017): Local environmental NGO roles in biodiversity governance: a Czech-German comparison. GeoScape 11(1): 1-15.

Slavíková L, Raška P (2019) This is my land! Privately funded natural water retention measures in the Czech Republic. In: Hartmann T, Slavíková L, McCarthy S (eds) Nature-based flood risk management on private land. Springer, Cham, pp. 55-67.

TNC (2020) About us. <https://www.nature.org/en-us/aboutus/who-we-are>
Valentinov V (2009) Toward an economics of the rural third sector. International Journal of Agricultural Resources, Governance and Ecology 8(5): 439-456.

Valentinov V, Hielscher S, Pies I (2015) Nonprofit organizations, institutional economics, and system thinking. Economic Systems 39: 491-501.

Wandel J, Valentinov V (2014) The nonprofit catallaxy: an Austrian economics perspective on the nonprofit sector. Voluntas 25: $138-149$.

Wätzold F, Schwerdtner K (2005) Why be wasteful when preserving a valuable resource? A review article on the costeffectiveness of European biodiversity conservation policy. Biological Conservation 123(3): 327-338.

Will M G, Roth S, Valentinov V (2018). From nonprofit diversity to organizational multifunctionality: a systems-theoretical proposal. Administration and Society 50(7): 1015-1036. 